\title{
Calcium-mediated gelation of an olive pomace pectic extract
}

\author{
Susana M. Cardoso ${ }^{\mathrm{a}, \mathrm{b}}$, Manuel A. Coimbra ${ }^{\mathrm{a}}$, J.A. Lopes da Silva ${ }^{\mathrm{a}, *}$ \\ a Departamento de Química, Universidade de Aveiro, 3810-193 Aveiro, Portugal \\ ${ }^{\mathrm{b}}$ Escola Superior Agrária de Bragança, 5301-855 Bragança, Portugal
}

Received 11 September 2002; accepted 12 September 2002

\begin{abstract}
Pectic raw material was extracted from the alcohol insoluble residue of olive pomace. After purification, the olive pectic extract (OPE) contained $48 \%$ of galacturonic acid (GalA) and $31 \%$ of arabinose, in a total sugar content of $72 \%$, and a degree of methylesterification (DM) of $43 \%$. Phase diagrams were established to define the physical state of the OPE/calcium systems, at $\mathrm{pH} 3$ and 7, as a function of GalA and calcium concentration. The rheological properties of the OPE/calcium systems were investigated by small-amplitude oscillatory tests. Kinetics of gel ageing and the viscoelastic properties of the cured gels were evaluated as a function of GalA and calcium concentration at $\mathrm{pH}$ 3 and 7. Compared with the observed behaviour of a citrus pectin, taken as representative of a commercial low-methoxyl pectin, the OPE showed higher critical GalA and calcium concentrations for gelation to occur, a larger region corresponding to homogeneous gel, and gels characterised by lower viscoelastic moduli, at similar GalA and calcium concentrations.
\end{abstract}

(C) 2003 Elsevier Science Ltd. All rights reserved.

Keywords: Olive pomace; Pectic polysaccharide; Gelation; Viscoelastic properties

\section{Introduction}

Pectins are natural hydrocolloids found in higher plants that are widely used as gelling agents, stabilizers, and emulsifiers in the food industry (May, 1990; Voragen, Pilnik, Thibault, Axelos, \& Renard, 1995). Basically, they are complex polysaccharides containing 1,4-linked- $\alpha$-D-galactosyluronic acid residues that are occasionally interrupted by $(1 \rightarrow 2)-\alpha$-L-rhamnose residues carrying sugar side chains, typically galactose and arabinose (Ridley, O'Neill, \& Mohnen, 2001; Willats, McCartney, Mackie, \& Knox, 2001). The gelation mechanism is highly dependent on the DM. Pectins of low-methoxyl content form gels through ionic interchain association (Morris, Powel Gidley, \& Rees, 1982; Powel, Morris, Gidley, \& Rees, 1982), in a similar manner to the 'egg-box model' proposed for alginates (Grant, Morris, Rees, Smith, \& Thom, 1973). This gelling capacity is also dependent on other structural properties, namely, the acetylation degree (DA), the molecular weight and the number and size of side chains (Voragen et al., 1995).

\footnotetext{
* Corresponding author. Fax: + 351-234-370084.

E-mail address: jsilva@dq.ua.pt (J.A. Lopes da Silva).
}

Commercial pectins are only available from two important sources: apple pomace and citrus peels. The availability of other pectic sources is always being searched, and the possibility of using waste products as raw materials is an important economical aspect. The waste beet solids from sugar extraction and the sunflower heads residues obtained after the oil extraction were very promising sources as they contain $10-20 \%$ of pectic material (Kalapathy \& Proctor, 2001; May, 1990). However, pectins obtained from those sources have poor gelling ability and those two raw materials have low commercial value.

In this work we intended to study the profit for the pectic extraction from the waste residue originated in the olive oil production by a continuous biphasic extraction system. In the traditional press method and in the continuous triphasic process, the resultant pomace is quite dry and is usually used for the extraction of olive pomace oil with hexane, which has a high added value. However, the use of these two extraction processes also produces the vegetative waters, which contain powerful pollutants (Saviozzi, Riffaldi, Levi-Minzi, Scagnozzi, \& Vanni, 1993). Due to the environmental problems, many of the industries involved in the olive oil production are now using the continuous biphasic extraction system (Civantos, 1999; Di Giovacchino, 1994). In this new process, only the oil and 
the residue phases are produced in high quantities. However, due to the retention of the fruit's water in the residue, the olive pomace obtained is very wet and, because of the energy required in the drying process, it does not have a significant commercial value (Civantos, 1999).

The olive pulp cell walls are known to contain about one third of arabinose-rich pectic polysaccharides (Coimbra, Waldron, \& Selvendran, 1994). Therefore, in this work, we have studied the gelation potential of the pectic polysaccharides extracted from the olive pomace, using rheological methods, in order to search for new applications of this by-product.

\section{Material and methods}

\subsection{Samples origin}

Olive (Olea europaea, L.) pomace was collected at Prolagar, Mirandela, Portugal. The pomace was obtained by crushing the olives (20\% Verdeal and $80 \%$ Santulhana cultivars) below $40{ }^{\circ} \mathrm{C}$, with a residence period on the sequential extractor of $45 \mathrm{~min}$. The pomace was separated from the olive oil by centrifugation.

Citrus low-methoxyl pectin (LMP) with a GalA content of $89 \%$ and a DM of $35 \%$ was obtained from HP Bulmer Ltd (England).

\subsection{Preparation of cell wall material}

Fresh olive pomace $(10 \mathrm{~kg})$ was dispersed in ethanol at a final concentration of $85 \%(\mathrm{v} / \mathrm{v})$ and boiled for $10 \mathrm{~min}$. The mixture was cooled, filtered through a glass fibre filter (Whatman GF/C) and the residue was then extracted twice with chloroform/methanol $(2: 1, \mathrm{v} / \mathrm{v}, 3 \times$ initial fresh weight) for $30 \mathrm{~min}$ under reflux in order to remove the oil. The resulting residue was washed with diethyl ether, acetone and allowed to dry at room temperature. The dried material $(3.3 \mathrm{~kg})$ was sieved to remove the smashed particles of the stone seed and the fruit peel, and the remaining material $(1.3 \mathrm{~kg})$, composed of olive pulp cell walls and of powdered olive stone was named the alcohol insoluble residue (AIR).

\subsection{Isolation of the pectic raw material}

The AIR was extracted with $\mathrm{HNO}_{3} 0.02 \mathrm{~mol} / \mathrm{l}(1 \mathrm{l}$ for each $50 \mathrm{~g}$ of AIR) at $80^{\circ} \mathrm{C}$ for $1.5 \mathrm{~h}$. After the extraction, the solubilised material was separated from the residue by filtration through a glass fibre filter (Whatman GF/C) and was concentrated at about six times the initial volume by rotary evaporation at $37^{\circ} \mathrm{C}$. The resultant solution was submitted to precipitation with $50 \%$ (v/v) of ethanol and the precipitate was collected by filtration under vacuum through a G3 sintered glass filter, washed with absolute ethanol, acetone and diethyl ether and allowed to dry at room temperature.

\subsection{Purification of pectic raw extract}

The pectic rich extract $(45.5 \mathrm{~g})$ was dispersed in EDTA $2.5 \%(\mathrm{w} / \mathrm{v})$, stirred for $24 \mathrm{~h}$ at $4{ }^{\circ} \mathrm{C}$ and dialysed against water. The pectin dispersion was percolated through a strong resin exchanger $\left(\mathrm{H}^{+}\right.$-form Amberlite IR-120, Fluka) and re-precipitated with acetone $80 \%(\mathrm{v} / \mathrm{v})$. The obtained residue (purified olive pectic extract, OPE) was washed with diethyl ether and allowed to dry at room temperature $(23.3 \mathrm{~g})$.

\subsection{Anion-exchange chromatography}

OPE (228 mg) was suspended in water and stirred overnight at room temperature. The insoluble residue was removed by centrifugation and sodium phosphate buffer $(\mathrm{pH}$ 6.5) was added to the supernatant to a final concentration of $50 \mathrm{mmol} / \mathrm{l}$ and $1.3 \mathrm{mg} / \mathrm{ml}$ of material. The solution was then passed through a column of DEAE-Sepharose in the phosphate form, at $20 \mathrm{ml} / \mathrm{h}$. The fractions were eluted sequentially with the same volume of buffer containing 0 ; $0.125 ; 0.250 ; 0.50$ and $1.0 \mathrm{~mol} / 1 \mathrm{NaCl}$. Fractions of $2.5 \mathrm{ml}$ were collected and assayed at $\lambda 280 \mathrm{~nm}$ for phenolics and/or protein and by the phenol $-\mathrm{H}_{2} \mathrm{SO}_{4}$ method for carbohydrate (Dubois, Gilles, Hamilton, Rebers, \& Smith, 1956). Appropriate fractions were pooled, dialysed and freezedried.

\subsection{Moisture, ash and mineral content}

The moisture content was determined by oven drying $2-5 \mathrm{~g}$ of samples at $105^{\circ} \mathrm{C}$ for $4 \mathrm{~h}$, plus $2 \mathrm{~h}$ to confirm weight stabilisation.

Ash content was determined by heating the samples at $650{ }^{\circ} \mathrm{C}$ for $4 \mathrm{~h}$ in a muffle furnace.

For the mineral analysis, samples $(0.025 \mathrm{~g})$ were digested with $5 \mathrm{ml}$ of concentrated $\mathrm{HNO}_{3}$ and $1 \mathrm{ml}$ of $30 \% \mathrm{H}_{2} \mathrm{O}_{2}$, at $120{ }^{\circ} \mathrm{C}$, until the acid was evaporated and the resulting residue was dissolved in $1 \mathrm{ml}$ of concentrated $\mathrm{HNO}_{3}$, diluted with water to $25 \mathrm{ml}$, and analysed by ICP-OES (inductively coupled plasma-optical emission spectroscopy) in a Jy 70 plus (Jobin Yvon) spectrometer.

\subsection{Protein analysis and determination of total phenolic content}

Protein determination was performed by first digesting the samples $(50 \mathrm{mg})$ with $2 \mathrm{ml}$ of concentrated $\mathrm{H}_{2} \mathrm{SO}_{4}$, $10 \mathrm{mg}$ of selenium and $0.350 \mathrm{~g}$ of $\mathrm{K}_{2} \mathrm{SO}_{4}$, in a Tecator heating block $\left(400{ }^{\circ} \mathrm{C}\right)$, followed by a colorimetric determination of the total nitrogen (Willis, Montgomery, \& Allen, 1996). The protein content was calculated using a conversion factor of 6.25 . 
Total phenolic content was determined spectrophotometrically by a modified Prussian Blue method (Price \& Butler, 1977): $5 \mathrm{ml}$ of water, $0.5 \mathrm{ml}$ of $0.1 \mathrm{~mol} / 1 \mathrm{FeCl}_{3}$ in $0.1 \mathrm{~mol} / 1$ $\mathrm{HCl}$ and $0.5 \mathrm{ml}$ of $8 \mathrm{mmol} / \mathrm{l} \mathrm{K}_{3} \mathrm{Fe}(\mathrm{CN})_{6}$ were added to $0.1 \mathrm{ml}$ of a freshly prepared pectic solution, the mixture was allowed to rest for $10 \mathrm{~min}$, and the absorbance measured at $720 \mathrm{~nm}$. Chlorogenic acid was used as a standard.

\subsection{Sugar composition and content of uronic acids}

Neutral sugar was determined by gas-liquid chromatography after sulphuric acid hydrolysis (Selvendran, March, \& Ring, 1979) and conversion to their alditol acetates (Blakeney, Harris, Henry, \& Stone, 1983; Harris, Blakeney, Henry, \& Stone, 1988) in a Carlo Erba 6000 gas chromatograph equipped with a split injector (split ratio $1: 60)$ and a flame ionisation detector (FID). The column was a DB-225 $(30 \mathrm{~m} \times 0.25 \mathrm{~mm}$, film thickness of $0.25 \mu \mathrm{m}$, $\mathrm{J} \& \mathrm{~W})$ and the oven temperature program was: $5 \mathrm{~min}$ at $220^{\circ} \mathrm{C}$, rising to $230{ }^{\circ} \mathrm{C}$ at $20^{\circ} \mathrm{C} / \mathrm{min}$, plus $6 \mathrm{~min}$ at this temperature. The flow rate of the carrier gas $\left(\mathrm{H}_{2}\right)$ was set at $1 \mathrm{ml} / \mathrm{min}$ at $220^{\circ} \mathrm{C}$. The injector temperature was $220^{\circ} \mathrm{C}$ and the FID temperature was $230{ }^{\circ} \mathrm{C}$.

Uronic acids were determined colorimetrically by a modification (Coimbra, Delgadillo, Waldron, \& Selvendran, 1996) of the method of Blumenkrantz and Asboe-Hansen (1973). Samples were prepared by hydrolysis in $0.2 \mathrm{ml}$ of $72 \% \mathrm{H}_{2} \mathrm{SO}_{4}$ for $3 \mathrm{~h}$ at $20{ }^{\circ} \mathrm{C}$ followed by $1 \mathrm{~h}$ in $1 \mathrm{~mol} / 1 \mathrm{H}_{2} \mathrm{SO}_{4}$ at $100{ }^{\circ} \mathrm{C}$. Calibration was made with $\mathrm{D}$-galacturonic acid.

\subsection{Degree of methylesterification and acetylation}

The determination of the DM and DA of the pectic polysaccharides was based on the estimate of methanol and acetic acid contents released by saponification (Waldron \& Selvendran, 1990). Methanol released after saponification of samples was determined as described previously (Barros et al., 2002). Acetic acid released under the same saponification conditions was determined by HPLC on an Aminex HPX-87H column at $30{ }^{\circ} \mathrm{C}$. The column was eluted with $0.5 \mathrm{mmol} / \mathrm{H}_{2} \mathrm{SO}_{4}$ at $0.5 \mathrm{ml} / \mathrm{min}$ with $\mathrm{UV}$ detection at $210 \mathrm{~nm}$. The DM and DA were calculated as the molar ratios of methanol and acetic acid to galacturonic acid.

\subsection{Preparation of the gels}

The pectin sample (OPE or LMP) was dispersed overnight in $0.1 \mathrm{~mol} / 1 \mathrm{NaCl}$ (deionised water) containing $0.02 \%$ of sodium azide as a preservative. The $\mathrm{pH}$ was adjusted to 7.0 or 3.0 with $0.1 \mathrm{~mol} / \mathrm{l} \mathrm{NaOH}$. To prepare the pectin-calcium systems, $1 \mathrm{~g}$ of pectic dispersion of different concentrations was pre-heated for $3 \mathrm{~min}$ at $70^{\circ} \mathrm{C}$, and $1 \mathrm{ml}$ of a calcium chloride solution (in $0.1 \mathrm{~mol} / \mathrm{l} \mathrm{NaCl}$ ) of appropriate concentrations was added drop wise while stirring the pectic dispersion. The total heating time at $70{ }^{\circ} \mathrm{C}$ was 6 min. After preparation, the sample was used either for the phase diagram study or in the rheological experiments.

\subsection{Phase diagrams}

After preparation of the pectin/calcium system, the sample was poured into glass tubes $(96 \mathrm{~mm}$ length, $9 \mathrm{~mm}$ internal diameter), closed, and allowed to stand for $48 \mathrm{~h}$ at $20{ }^{\circ} \mathrm{C}$. The tubes were then gently tilted and the physical state of the sample was assessed visually, following the criteria of Garnier, Axelos, and Thibault (1993). If the solution flowed, it was defined as a sol, and if the sample did not flow or deform under its own weight, the system was considered a gel. When the onset of deformation of the sample flowing slowly, the system was considered to be in the transition between the sol and gel states. Syneresis was detected by the presence of water at the gel surface.

\subsection{Rheological assays}

Dynamic rheological measurements were performed using a CVO HR 120 rheometer (Bohlin Instruments) with cone $\left(4^{\circ}, \varnothing 40 \mathrm{~mm}\right)$ and plate geometry (gap $\left.150 \mu \mathrm{m}\right)$. The hot sample solution was loaded onto the pre-heated plate of the rheometer $\left(70{ }^{\circ} \mathrm{C}\right)$ immediately after preparation, and the temperature was rapidly lowered to $20^{\circ} \mathrm{C}$ (Peltier system). A layer of low viscosity mineral oil was loaded onto the exposed edge of sample to minimise water evaporation. The curing time experiments were performed for $20 \mathrm{~h}$ at $20{ }^{\circ} \mathrm{C}$ and the changes in storage modulus $\left(G^{\prime}\right)$ and loss modulus $\left(G^{\prime \prime}\right)$ were recorded at $1 \%$ strain and frequency of $1 \mathrm{~Hz}$. Viscoelastic properties of the cured gels were assessed by frequency sweep tests over the range $0.005-5 \mathrm{~Hz}$ at $1 \%$ strain.

\section{Results and discussion}

\subsection{Isolation, purification and characterization of the pectic rich extract}

The AIR, the residue after removal of the smashed hard seeds, accounted for $31 \%$ of the starting material (dry weight basis). The sugar composition of the AIR is shown in Table 1. Polysaccharides accounted for $47 \%$ of the residue and were mainly composed of glucose (Glc, 40\%), xylose (Xyl, 28\%), galacturonic acid (GalA, 14\%) and arabinose (Ara, 11\%). The yield of AIR and its total sugar content were similar to those previously obtained (Cardoso, Silva, \& Coimbra, 2002). Some differences were observed in the sugar composition and galacturonic acid content, likely associated to different factors, including the cultivar, the harvest season and the maturation stage of the olive pomace used as the starting material (Mafra et al., 2000). Still, the AIR sugar composition of our sample is in accordance with the results of Vierhuis (2002) obtained for olive pomace 
Table 1

Sugar composition of the pectic material extracted from the olive pomace and of the fractions obtained by anionic exchange chromatography

\begin{tabular}{|c|c|c|c|c|c|c|c|c|c|c|}
\hline \multirow[t]{2}{*}{ Fraction } & \multirow[t]{2}{*}{ Recovery (\%) } & \multirow[t]{2}{*}{$\mathrm{DE}(\%)$} & \multicolumn{7}{|c|}{ Cell wall sugars $(\mathrm{mol} \%)$} & \multirow[t]{2}{*}{ Total sugar ${ }^{\mathrm{a}}(\mathrm{mg} / \mathrm{g}$} \\
\hline & & & Rha & Ara & Xyl & Man & Gal & Glc & GalA & \\
\hline AIR & $13.5^{\mathrm{b}}$ & ND & $1.5 \pm 0.1$ & $11.2 \pm 0.7$ & $28 \pm 3$ & $2.6 \pm 0.4$ & $3.6 \pm 0.4$ & $40 \pm 2$ & $13.6 \pm 0.3$ & $471 \pm 9$ \\
\hline Raw extract & $3.7^{\mathrm{c}}$ & 31 & $2.3 \pm 0.6$ & $26 \pm 1$ & $1.1 \pm 0.4$ & $0.8 \pm 0.4$ & $9.5 \pm 0.8$ & $6.0 \pm 0.4$ & $54 \pm 1$ & $603 \pm 12$ \\
\hline Purified extract & $51.2^{\mathrm{d}}$ & 43 & $3.7 \pm 0.4$ & $31 \pm 1$ & $\mathrm{t}$ & - & $10 \pm 1$ & $6.9 \pm 0.5$ & $48 \pm 2$ & $721 \pm 24$ \\
\hline I & $25.2^{\mathrm{e}}$ & 45 & $3.4 \pm 0.4$ & $47 \pm 2$ & $3.4 \pm 0.4$ & $\mathrm{t}$ & $16 \pm 1$ & $11 \pm 1$ & $18 \pm 1$ & $721 \pm 47$ \\
\hline IIA & $16.8^{\mathrm{e}}$ & 73 & $3.3 \pm 0.3$ & $19 \pm 3$ & $1.4 \pm 0.8$ & - & $11 \pm 1$ & $3.0 \pm 0.5$ & $62 \pm 3$ & $642 \pm 30$ \\
\hline IIB & $6.2^{\mathrm{e}}$ & 46 & $3.9 \pm 0.4$ & $18 \pm 1$ & $1.2 \pm 0.2$ & $\mathrm{t}$ & $9.3 \pm 0.8$ & $2.4 \pm 0.1$ & $64 \pm 2$ & $672 \pm 24$ \\
\hline III & $32.1^{\mathrm{e}}$ & 28 & $4.1 \pm 0.8$ & $15.7 \pm 0.4$ & $\mathrm{t}$ & - & $6.9 \pm 0.4$ & $\mathrm{t}$ & $71.8 \pm 0.8$ & $671 \pm 7$ \\
\hline IV & $1.6^{\mathrm{e}}$ & ND & 4.9 & 28.4 & 2.9 & 0.7 & 16.5 & 7.7 & 39.0 & 411 \\
\hline $\mathrm{V}$ & $2.8^{\mathrm{e}}$ & ND & 2.5 & 14.8 & 11.5 & 21.3 & 15.4 & 24.8 & 9.5 & 150 \\
\hline
\end{tabular}

t: trace amounts; ND: not determined.

a Values are expressed as mg of anhydrosugar/g polymer.

b Recovery is expressed as a percentage of fresh olive pomace.

c Recovery is expressed as a percentage of the AIR.

d Recovery is expressed as a percentage of raw extract.

e Recovery is expressed as a percentage of the purified extract.

produced from olives of the Moraiolo variety. In general, the AIR composition suggests the presence of polysaccharides (cellulose, glucuronoxylans, xyloglucans and pectic polysaccharides rich in arabinose) that have been described to occur in olive pulp (Araujo, Labavitch, \& Moreno, 1994; Coimbra et al., 1994; Huisman, Schols, \& Voragen, 1996; Mafra et al., 2000).

The pectic raw material extracted with hot diluted acid represented $3.7 \%$ of the AIR, with a total sugar content of $60 \%$ (Table 1). This pectic rich fraction was mostly composed of GalA and Ara in a ratio near 2:1, plus Gal $(10 \%)$, Glc (6\%) and Rha (2\%). Contrarily to what happens with commercial pectins, that are slightly branched, the extraction of pectic polysaccharides rich in Ara by hot diluted acid as been reported for the olive pomace (Cardoso et al., 2002) as for other different sources, like sugar beet (Khalid, Renard, R'zina, \& Thibault, 2001; Micard \& Thibault, 1999), cherry fruits (Barbier \& Thibault, 1982) and glassworts (Renard, Champenois, \& Thibault, 1993). The pectic raw material extracted from the olive pomace had a DM of $31 \%$. Its protein and phenolic content accounted for 4.3 and $5.2 \%$, respectively. Ash represented $11.5 \%$, mainly contributed by potassium and calcium cations (Table 2). In order to diminish the ionic content of the pectic material, the raw extract was subjected to a purification procedure by EDTA complexation, followed by percolation through a strong resin ionic exchanger. As can be seen in Table 2 , the purification process greatly reduced the ash content from 11.5 to $1.1 \%$ and calcium accounted only for $0.03 \%(\mathrm{w} / \mathrm{w})$ of the mineral fraction. Proteins and phenolics were lowered to 3.0 and 3.1, respectively. The purified pectic material obtained had a higher polysaccharide content (72\%) as compared to the raw material (Table 1). Still, this process reduced the proportion of GalA in relation to the neutral sugars content in the pectic extract. As the DM of the purified pectic polysaccharides is greater
(43\% compared to $31 \%$ of the raw pectic material), the combined results suggest that during the purification step some pectic less-branched material of lower DM was lost. The acetyl content of the purified fraction was $11 \%$.

The fractionation of the OPE by ion exchange chromatography on DEAE-Sepharose (Fig. 1) originated six main different fractions, corresponding to $84.8 \%$ of the starting material (OPE). Most of the polysaccharides were eluted in the first four fractions, which accounted for $95 \%$ of the total recovered material. The non-retained material (fraction I) represented $25 \%$ of the OPE, and was very rich in Ara $(47 \%)$ as compared to GalA (18\%). Other neutral sugars detected were Gal (16\%), Glc (11\%), Rha (3\%) and Xyl (3\%). The DM of this fraction was close to the mean value of the starting pectic material. Two well-defined fractions were obtained for the elution with $0.125 \mathrm{~mol} / 1 \mathrm{NaCl}$. They both contain a ratio GalA/Ara near 3:1, and close

Table 2

Non-sugar composition of the raw and the purified pectic extracts of olive pomace

\begin{tabular}{|c|c|c|}
\hline & Raw extract & Purified extract \\
\hline Moisture & 10 & 13 \\
\hline Protein & 4.3 & 3.0 \\
\hline Phenolics & 5.2 & 3.1 \\
\hline Ash & 11.5 & 1.1 \\
\hline \multicolumn{3}{|c|}{ Metal content ${ }^{\mathrm{a}}$} \\
\hline Calcium & 25.0 & 0.33 \\
\hline Copper & 0.061 & $<0.01$ \\
\hline Lead & $<0.05$ & $<0.02$ \\
\hline Iron & 0.43 & 0.040 \\
\hline Magnesium & 2.21 & 0.080 \\
\hline Sodium & 0.15 & 1.04 \\
\hline Potassium & 31.6 & 0.14 \\
\hline
\end{tabular}

Values are expressed as \% and calculated on a dry weigh basis (except for moisture).

${ }^{\mathrm{a}}$ Mean values of two determinations and expressed as $\mathrm{mg} / \mathrm{g}$. 


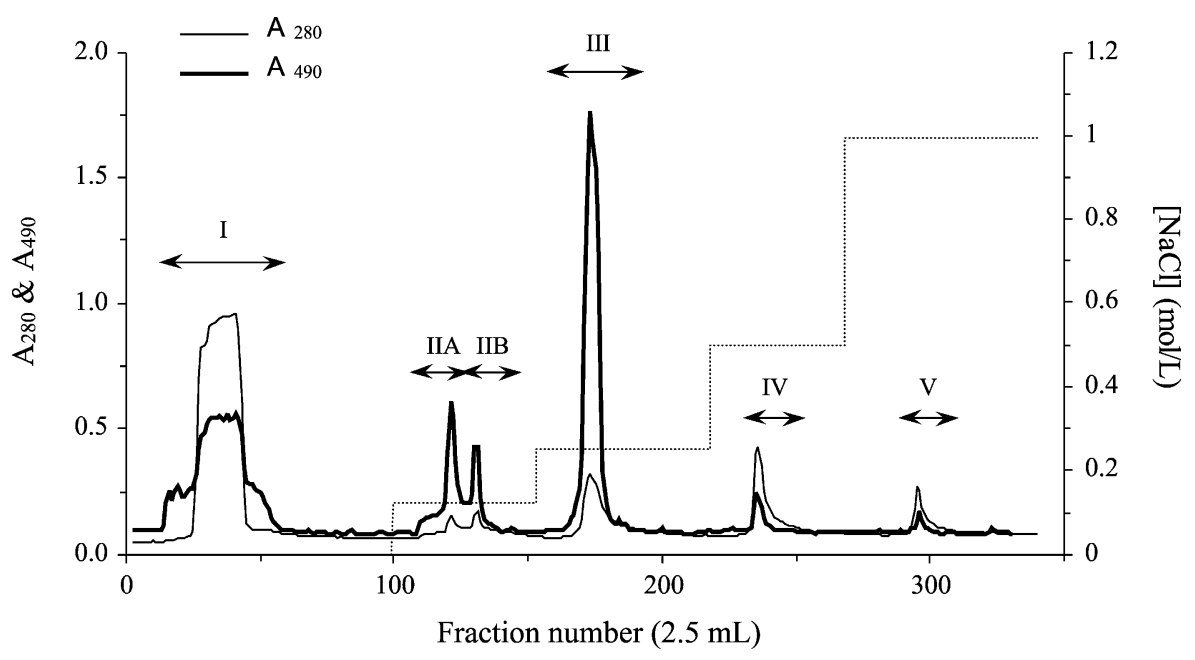

Fig. 1. Anionic exchange cromatography in DEAE-Sepharose of the pectic purified extract from olive pomace.

proportions of Gal $(9-11 \%)$, Rha (3-4\%), Glc $(2-3 \%)$ and Xyl $(1 \%)$. The sugar analysis indicated that these two fractions could have a similar structural composition. Still, since the former fraction (IIA) had a higher DM as compared to fraction IIB, the charge of the polysaccharides in the two fractions was different and they could be separated on an anionic exchange chromatography. Fraction III, eluted with $0.25 \mathrm{~mol} / \mathrm{l} \mathrm{NaCl}$, was the most representative fraction (32\% recover). It had a polysaccharide content of $67 \%$ and GalA was the major component $(72 \%)$. Ara was still present in moderate amounts $(16 \%)$ and Rha and Gal were detected in lower quantity. This fraction had the lowest DM (28\%), justifying the strong association to the column gel. From the results of the anionic exchange chromatography, it was inferred that the purified extract is composed of heterogeneous polysaccharides, either in respect to sugar composition or to their charge. Also, as all the fractions contained GalA and Ara, it is inferred that the neutral sugars are mostly covalently associated with the (rhamno)galacturonan backbone. Proteins and/or phenolic compounds should also be associated with the pectic polymers since the sugar profile and that of $\mathrm{A}_{280}$ overlap.

\subsection{Phase diagrams}

Phase diagrams representing the physical state of the $\mathrm{OPE} /$ calcium and LMP/calcium systems, with respect to the GalA and calcium concentrations for $\mathrm{pH} 7$ and 3, in $0.1 \mathrm{~mol} / 1 \mathrm{NaCl}$, are shown in Fig. 2. As described for different pectins in the presence of divalent ions (Durand et al., 1990; Garnier, Axelos, \& Thibault, 1991; Lopes da Silva, Gonçalves, Doublier, \& Axelos, 1996), three regions were obtained: sol (region 1), homogeneous gel (region 2), and gel with syneresis (region 3 ). The boundary between 1 and 2 regions defined the calcium/GalA concentration relationship for the sol-gel transition to occur. This curve defined a critical GalA concentration $\left(C_{0}\right)$, i.e. the minimum polymer amount able to gel, below which gelation could not occur, independently of the calcium added to the system. The sol-gel transition curve also defined a critical calcium concentration $\left(C_{1}\right)$, corresponding to the minimum calcium required for gelation to occur whatever the polymer concentration. Homogeneous gels were obtained above $C_{1}$ and in the presence of enough polymer. However, if calcium was raised to higher concentrations, an excess of cations
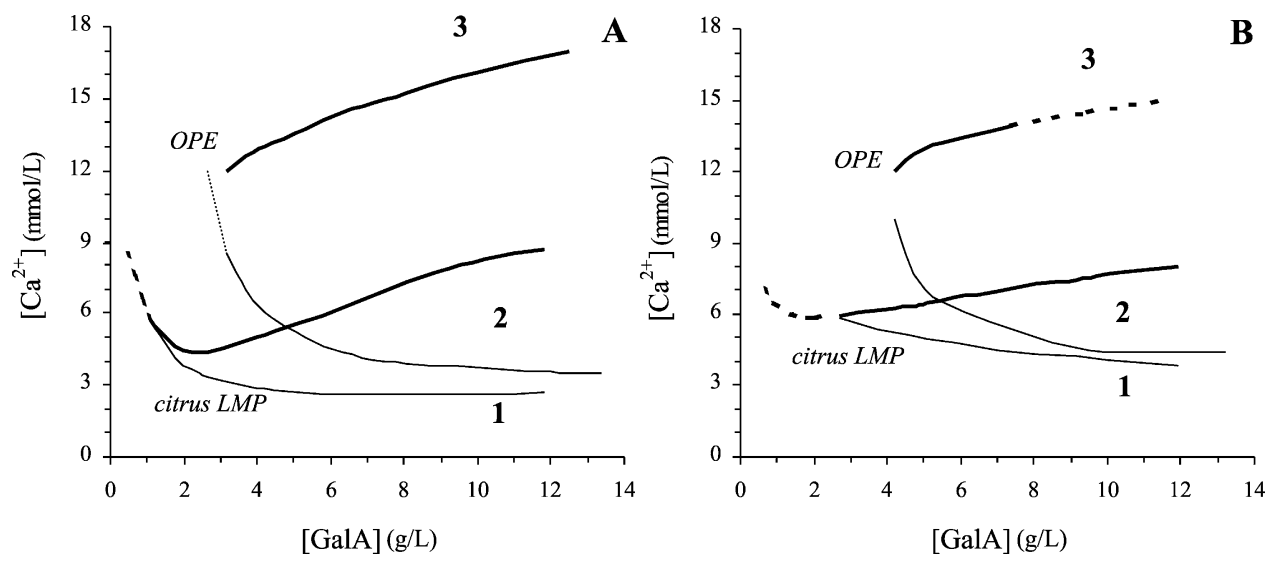

Fig. 2. Phase diagrams for OPE and citrus LMP in $0.1 \mathrm{~mol} / \mathrm{l} \mathrm{NaCl}$ at $20^{\circ} \mathrm{C}$, as a function of GalA and calcium concentrations for (A) $\mathrm{pH} 7$ and (B) $\mathrm{pH} 3$. Dotted lines denote less defined transitions. 
occurred in relation to the polymer concentration, and demixing took place. The transition between a homogeneous gel and demixing is represented in Fig. 2A and B by the delimitation curve between region 2 and 3. Above that curve, gels with syneresis were obtained for high OPE concentrations, while precipitation was observed for lower OPE concentrations. The phase diagram obtained for the $\mathrm{LMP} /$ calcium systems at $\mathrm{pH} 7$ established the critical GalA and calcium concentrations as $\approx 1 \mathrm{~g} / \mathrm{l}$ and $2.5 \mathrm{mmol} / \mathrm{l}$, respectively. These values are in accordance with those reported for apple and other citrus commercial pectins (Axelos \& Kolb, 1991; Durand et al., 1990; Garnier et al., 1993). As compared to the commercial pectin, the OPE/ calcium system showed higher $C_{0}$ and $C_{1}$ values $(2.8 \mathrm{~g} / \mathrm{l}$ and $4 \mathrm{mmol} / \mathrm{l}$ ). Probably, the differences can be ascribed to two main structural aspects, namely: (1) the higher methyesterification degree of the OPE, diminishing the number of available sites for ionic junctions and (2) its higher amount of side branches, hindering the approximation of the pectic chains and the access of calcium to the joint points, and consequently, the establishment of effective junction zones. The relative importance of each of those factors is difficult to discriminate, but likely the different amount of side branches is playing the main role. In fact, it was previously shown that the variation of the DM between 28 and $44 \%$ do not significantly affect the $C_{0}$ and $C_{1}$ parameters for commercial pectins (Garnier et al., 1993).

Syneresis was detected for much higher calcium concentration in the OPE/calcium systems compared to the commercial pectin, and consequently a much larger zone in which homogeneous gels were obtained is observed (Fig. 2A). Since the occurrence of biphasic gels has been attributed to the existence of a large number of intramolecular links leading to the contraction of the polymer chains (Allain \& Salomé, 1990) and the exclusion of solvent, the late appearance of syneresis in the PPE/calcium systems can also be related to a possible obstruction of the side chains on the formation of intramolecular cross links.

Fig. 2B shows the phase diagrams obtained at $\mathrm{pH} 3$. The critical GalA concentration was higher and the sol-gel transition occurred for higher calcium amounts than at $\mathrm{pH} 7$. This can be explained by the low ionisation of the carboxyl groups at $\mathrm{pH} \mathrm{3,} \mathrm{decreasing} \mathrm{the} \mathrm{possibility} \mathrm{of} \mathrm{cross-link}$ formation. At $\mathrm{pH} 3$, the region of homogeneous gel was also narrower than that for $\mathrm{pH} 7$, suggesting that in addition to the ionic complexation, important aggregation of pectic chains occurs when the number of carboxylate groups is lower.

\subsection{Viscoelastic behaviour of the OPE/calcium systems}

The evolution of the viscoelastic properties as a function of ageing time for the OPE/calcium systems was investigated at $\mathrm{pH} 7$ and 3 . Representative curing curves are shown in Fig. 3 for two different amounts of calcium, 5 and $10 \mathrm{mmol} / \mathrm{l}$, corresponding to the vicinity of the sol-gel point and to the middle of the homogenous gel region,

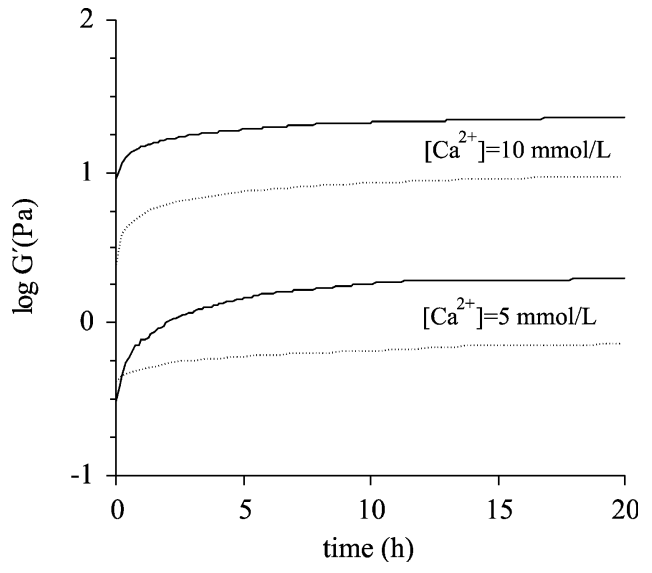

Fig. 3. Kinetics of gel formation measured at $20^{\circ} \mathrm{C}, 1 \mathrm{~Hz}$, for pectin/calcium systems with similar polygalacturonate content $(\mathrm{GalA}]=10 \mathrm{~g} / \mathrm{l})$ and different calcium concentrations, at $\mathrm{pH} 7$ (full lines) and $\mathrm{pH} 3$ (dotted lines).

respectively. For both $\mathrm{pHs}$, the $G^{\prime}(t)$ increased rapidly in the first $1-2 \mathrm{~h}$, after which the evolution was slower and tended to an asymptotic value. This behaviour is in agreement with the general profile described for the gelation process of pectins and other biopolymers (Axelos, Lefebvre, Qiu, \& Rao, 1991; Clark \& Ross-Murphy, 1987; Lopes da Silva \& Gonçalves, 1994). The values of the loss modulus $\left(G^{\prime \prime}\right)$ did not vary significantly as a function of time (data not shown) and, for the systems with $10 \mathrm{~mol} / \mathrm{l}$ of calcium, this value was about 10 and 5 times less ( $\mathrm{pH} 7$ and 3, respectively) than that of $G^{\prime}$. Fig. 3 showed that an increment in the calcium concentration was followed by a large increase in the $G^{\prime}$ value obtained after $20 \mathrm{~h}$ of curing. As expected, for $\mathrm{pH} 3$ gels are more fragile. At this $\mathrm{pH}$, the carboxyl dissociation is very low and the ionic binding sites are lesser than at $\mathrm{pH} 7$. Instead, some other intermolecular interactions like hydrogen bond could be formed, but they are much weaker compared to the ionic cross-links that would be formed if the carboxyl groups were fully dissociated. Therefore, due to the lower availability of ionic binding points on the pectic backbone, cross-links will be scarce. Fig. 4 shows the mechanical spectra of the OPE/calcium systems obtained after $20 \mathrm{~h}$ of ageing. All the cured gels had predominantly a solid-like character, which was more pronounced for the system with $10 \mathrm{mmol} / \mathrm{l}$ of calcium, at pH 7 (Fig. 4A). For that system, $G^{\prime}$ was independent of the frequency over a range between 0.005 and $5 \mathrm{~Hz}$, and its magnitude, for lower frequencies, was about one decade larger than the $G^{\prime \prime}$. Still, for higher frequencies, $G^{\prime}$ and $G^{\prime \prime}$ were closer in magnitude, meaning that some molecular rearrangements can take place within the gel in the time scale analysed. The $G^{\prime}$ of the cured gels obtained for identical OPE/calcium concentrations at $\mathrm{pH} 3$ was about half of that obtained for $\mathrm{pH} 7$. At $\mathrm{pH} 3$, the lower availability of charged carboxyl groups results in more imperfect networks: $G^{\prime}$ was more dependent on the frequency, and $G^{\prime}$ and $G^{\prime \prime}$ values showed far smaller separation, clearly observed for higher frequencies, 

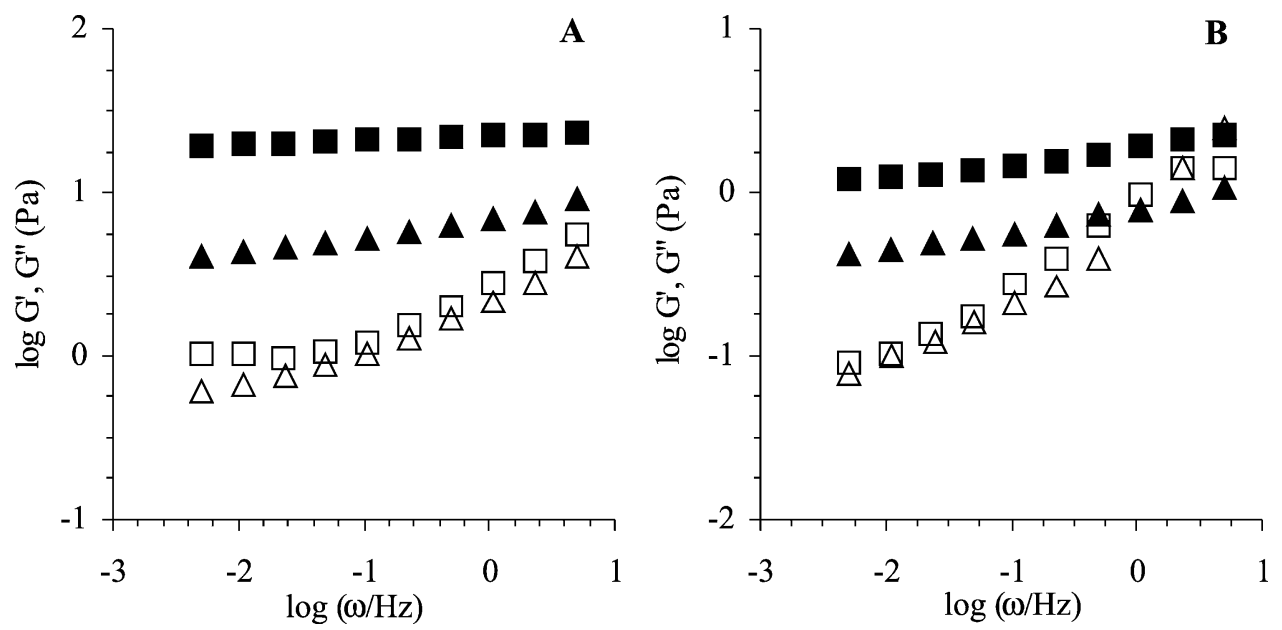

Fig. 4. Influence of $\mathrm{pH}$ on the mechanical spectra measured at $20^{\circ} \mathrm{C}$, after $20 \mathrm{~h}$ of curing, for the same systems shown in Fig. 3 , for $10 \mathrm{mmol} / \mathrm{l}$ calcium (A) and for $5 \mathrm{mmol} / \mathrm{l}$ calcium (B), at two different $\mathrm{pH}$ values (squares-pH 7; triangles-pH 3). Filled symbols denote for $G^{\prime}$ and open symbols for $G^{\prime \prime}$.

meaning a lower elastic character. As established by the phase diagram, $5 \mathrm{mmol} / \mathrm{l}$ of calcium is close to the critical calcium concentration for OPE/calcium systems. Despite the presence of the same polymer concentration, calcium is scarce and the number of cross-links established is lower, resulting in a very fragile gel structure. As a result, the viscoelastic modulus $G^{\prime}$ and $G^{\prime \prime}$ were both dependent on the frequency (Fig. 4B). After $20 \mathrm{~h}$ of ageing, the system cured at $\mathrm{pH} 3$ was slightly above the gel point, with $G^{\prime}$ higher than $G^{\prime \prime}$ in the lower frequency range, and a crossover of those two modulus for a frequency of about $1 \mathrm{~Hz}$.

\subsection{Dependence of the gel viscoelastic properties on the pectin and calcium concentrations}

The dependence of the storage modulus of OPE/calcium upon the calcium concentration after $20 \mathrm{~h}$ of ageing is represented in Fig. 5. For comparison, the same approach is shown for the citrus LMP/calcium systems. Data is shown for different pectin concentrations, expressed as the concentration of non-esterified carboxyl groups available in the pectin $\left(\mathrm{GalA}^{*}\right)$, in order to normalise the results with respect to the different degrees of methylesterification of the two pectins. At $\mathrm{pH} 7$, both pectic/calcium systems exhibited similar dependencies on the total calcium concentration added to the system, with a power law exponent around 3 (Fig. 5A). At pH 3, the commercial citrus pectin showed a more complex dependence of $G^{\prime}$ on calcium concentration, with at least two regions of different behaviour, depending on calcium concentration (Fig. 5B). However, for OPE/ calcium gels this dependence is clearly lower than at $\mathrm{pH} 7$ for all the calcium range analysed. For GalA* concentrations of 4.1 and 5.8, $G^{\prime}$ had a power law dependence on calcium concentration of 1.7 and 2.4, respectively (Fig. 5B). The different sensitivity to calcium of the OPE/calcium at $\mathrm{pH} 3$ probably results from a set of factors contributing,
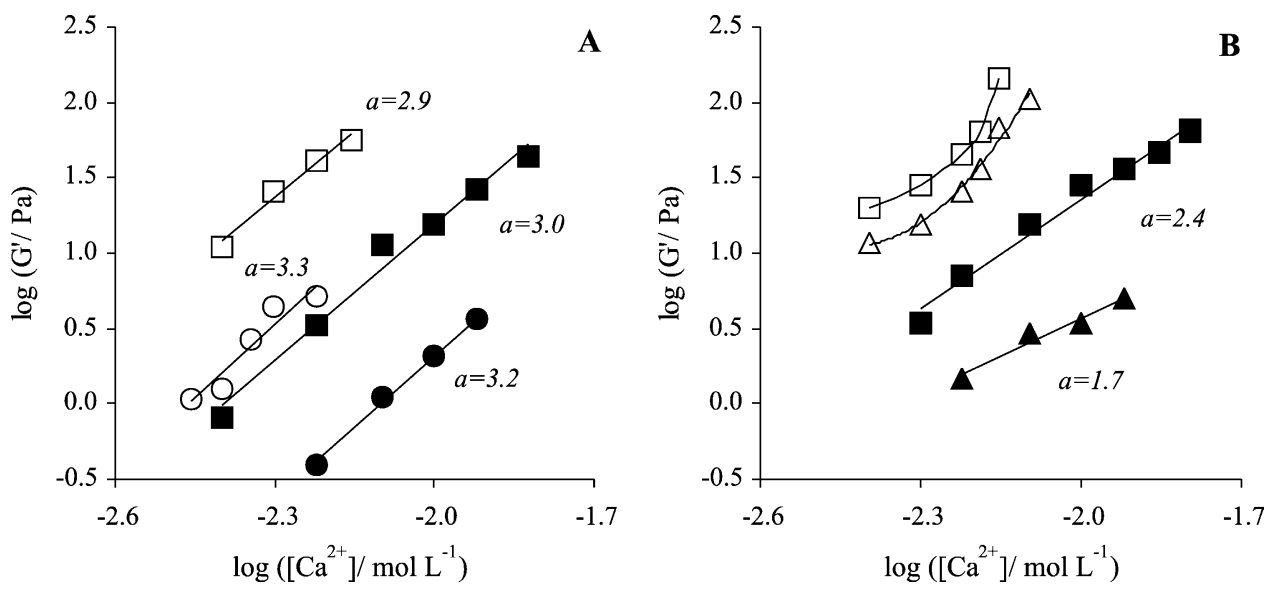

Fig. 5. Storage modulus $\left(G^{\prime}\right)$ measured for $20 \mathrm{~h}$ cured gels of OPE and LMP, at $20{ }^{\circ} \mathrm{C}$ in $0.1 \mathrm{~mol} / 1 \mathrm{NaCl}$, as a function of the calcium concentration at (A) pH 7

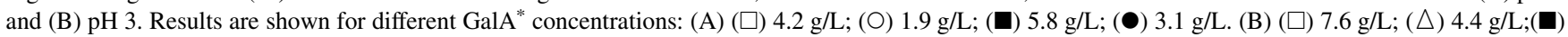
$7.5 \mathrm{~g} / \mathrm{L} ;(\boldsymbol{\Lambda}) 4.1 \mathrm{~g} / \mathrm{L}$. Filled symbols denote the OPE system and open symbols represent the LMP pectin system. Also shown are the exponents obtained from a power law relationship, $G^{\prime} \propto\left[\mathrm{Ca}^{2+}\right]^{a}$. 

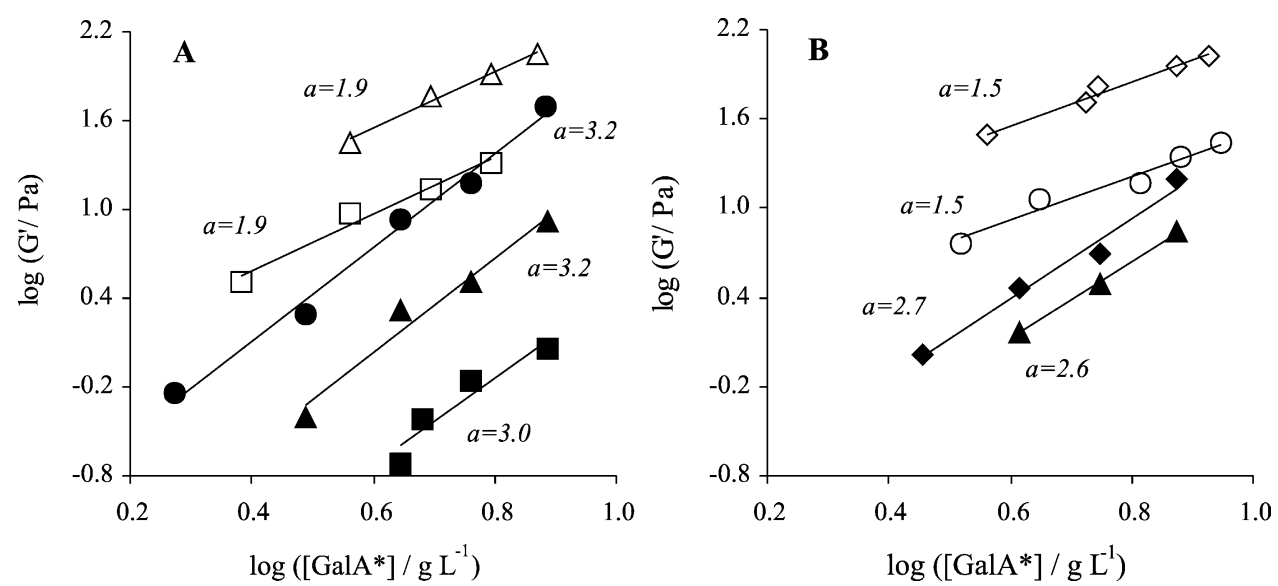

Fig. 6. Storage modulus $\left(G^{\prime}\right)$ measured for $20 \mathrm{~h}$ old gels of OPE and LMP, at $20^{\circ} \mathrm{C}$ in $0.1 \mathrm{~mol} / 1 \mathrm{NaCl}$, as a function of the GalA* content for $(\mathrm{A}) \mathrm{pH} 7$ and $(\mathrm{B})$ pH 3. Results are shown for different $\mathrm{Ca}^{2+}$ concentrations: $(\mathbf{\square}, \square) 4 \mathrm{mmol} / \mathrm{l} ;(\bigcirc) 5 \mathrm{mmol} / 1 ;(\boldsymbol{\Lambda}, \triangle) 6 \mathrm{mmol} / \mathrm{l} ;(\diamond) 7 \mathrm{mmol} / \mathrm{l} ;(\diamond) 8 \mathrm{mmol} / \mathrm{l} ;(\bullet) 10 \mathrm{mmol} / \mathrm{l}$. Filled symbols denote the OPE system and open symbols represent the LMP pectin system. Also shown are the exponents obtained from a power law relationship, $G^{\prime} \propto\left[\mathrm{GalA}^{*}\right]^{a}$.

together, to hinder the ion-galacturonate interactions, and thus to decrease the amount of effective cross links between pectic chains for the same calcium amount added to the system: lower ionisation degree of the carboxylate groups, lower number of free carboxylate groups, and higher amount of branch side chains. The data shown in Fig. 5 also confirm the lower capability of the OPE to form elastically effective junctions zones, under similar ionic conditions.

Fig. 6 shows the dependence of $G^{\prime}$ after $20 \mathrm{~h}$ of curing, on the polymer concentration for different calcium concentrations added to the pectic/calcium systems. At $\mathrm{pH} 7$, the OPE/calcium system showed a power law dependence with exponents around 3 for calcium concentrations of 4,6 and $10 \mathrm{mmol} / \mathrm{l}$ (Fig. 6A). For the citrus LMP/calcium system this dependence was around 2 for the different calcium concentrations used. From these results, we can conclude that within the OPE/ calcium network, the development of elastically effective junction zones, i.e. those contributing to the measured $G^{\prime}$ values, is more dependent on the amount of polymer than for the citrus commercial pectin. The differences on the polymer concentration dependencies of the two pectic/ calcium systems are still noted for $\mathrm{pH} 3$ (Fig. 6B). However, as a result of the reduction of the ionic charge of the polymer, both systems showed slightly lower increments on $G^{\prime}$ upon increasing the polymer concentration, at this $\mathrm{pH}$.

\section{Concluding remarks}

The purified pectic fraction obtained from the olive pomace was mainly composed of GalA and Ara (48 and $31 \%$, respectively) with a DM of $43 \%$. Its DEAESepharose elution pattern resulted in four major fractions, all containing GalA and Ara in different proportions, demonstrating that the OPE was polydisperse in relation to sugar composition and to charge density. Despite the high neutral sugar content and the relatively high methoxyl content, this pectic fraction formed elastic gels on addition of calcium, both at $\mathrm{pH} 7$ or 3 . As compared to a commercial pectin, the OPE showed higher critical concentrations $\left(C_{0}\right.$ and $\left.C_{1}\right)$, but also a much larger zone in which homogeneous gels was obtained. The kinetic of the formation of the OPE/calcium gels is in agreement with the general behaviour described for the gelation process of pectins and other biopolymers and, at $\mathrm{pH} 7$ and 3, higher values of the elastic modulus were obtained when rising the polymer and the calcium concentrations. At $\mathrm{pH} 7$, the storage modulus of the OPE/calcium gels showed a power law dependence on the calcium concentration, with an exponent similar to the commercial pectin. However, its dependency on the polymer concentration was higher than that observed for the citrus pectin. At $\mathrm{pH} \mathrm{3}$, more fragile gels were obtained with a generally lower dependence on calcium and on polymer concentration, due to the lower charge density. From these results, it could be inferred that olive pomace can be a potential source of gelling pectic material, with useful properties for particular applications.

\section{Acknowledgements}

The authors thank Prolagar (Mirandela, Portugal) for providing the olive pomace. Authors also acknowledge the Research Unit 62/94 of Química Orgânica, Produtos Naturais e Agro-Alimentares of University of Aveiro. Susana Cardoso was supported by a PhD grant PRODEP III 5.3/N/199.006/00. 


\section{References}

Allain, C., \& Salomé, L. (1990). Gelation of semidilute polymer solutions by ion complexation: Critical behaviour of the rheological properties versus cross-link concentration. Macromolecules, 23, 981-987.

Araujo, A. J., Labavitch, J. M., \& Moreno, A. H. (1994). Changes in the cell wall of olive fruit during processing. Journal of Agriculture and Food Chemistry, 42, 1194-1199.

Axelos, M. A. V., \& Kolb, M. (1991). Sol-gel transition in biopolymers. Die Makromolekulare Chemie, Macromolecular Symposia, 45, 23-30.

Axelos, M. A. V., Lefebvre, J., Qiu, C.-G., \& Rao, A. (1991). Rheology of pectin dispersions and gels. In R. H. Walter (Ed.), The chemistry and technology of pectin (pp. 227-250). San Diego: Academic Press.

Barbier, M., \& Thibault, J.-F. (1982). Pectic substances of cherry fruits. Phytochemistry, 21, 111-115.

Barros, A. S., Mafra, I., Ferreira, D., Cardoso, S., Reis, A., Lopes da Silva, J. A., Delgadillo, I., Rutledge, D. N., \& Coimbra, M. A. (2002). Determination of the degree of methylesterification of pectic polysaccharides by FT-IR using an outer product PLS1 regression. Carbohydrate Polymers, 50, 85-94.

Blakeney, A. B., Harris, P. J., Henry, R. J., \& Stone, B. A. (1983). A simple and rapid preparation of alditol acetates for monosaccharide analysis Carbohydrate Research, 113, 291-299.

Blumenkrantz, N., \& Asboe-Hansen, G. (1973). New method for quantitative determination of uronic acids. Analytical Biochemistry, $54,484-489$.

Cardoso, S. M., Silva, A. M. S., \& Coimbra, M. A. (2002). Structural characterisation of the olive pomace pectic polysaccharide arabinan side chains. Carbohydrate Research, 337, 917-924.

Civantos, L. (1999). Comparación entre sistemas de extracción. In L. Civantos (Ed.), Obtención del aceite de oliva virgen (pp. 189-201) Madrid: Editorial Agrícola Española.

Clark, A. H., \& Ross-Murphy, S. B. (1987). Structural and mechanical properties of biopolymer gels. Advances in Polymer Science, 83, $57-192$.

Coimbra, M. A., Delgadillo, I., Waldron, K. W., \& Selvendran, R. R. (1996). Isolation and analysis of cell wall polymers from olive pulp. In H. F. Linskens, \& J. F. Jackson (Eds.), (Vol. 17) (pp. 19-44). Modern methods of plant analysis, Berlin: Springer.

Coimbra, M. A., Waldron, K. W., \& Selvendran, R. R. (1994). Isolation and characterisation of cell wall polymers from olive pulp (Olea europeae L.). Carbohydrate Research, 252, 245-262.

Di Giovacchino, L. (1994). Resultados obtenidos de la extracción del aceite de las aceitunas com un nuevo decantador de dos fases. Olivae, 50 $42-44$.

Dubois, M., Gilles, K. A., Hamilton, J. K., Rebers, P. A., \& Smith, F. (1956). Colorimetric method for determination of sugars and related substances. Analytical Chemistry, 28, 350-356.

Durand, D., Bertrand, C., Busnel, J.-P., Emery, J., Axelos, M., Thibault, J.F., Lefebvre, J., Doublier, J. L., Clark, A. H., \& Lips, A. (1990). Physical gelation induced by ionic complexation: Pectin-calcium systems. In W. Burchard, \& S. B. Ross-Murphy (Eds.), Physical networks-Polymers and gels (pp. 283-300). Barking: Elsevier Applied Science.

Garnier, C., Axelos, M. A. V., \& Thibault, J.-F. (1991). Dynamic viscoelasticity and thermal behaviour of pectin-calcium gels. Food Hydrocolloids, 5, 105-108.

Garnier, C., Axelos, M. A. V., \& Thibault, J.-F. (1993). Phase diagrams of pectin-calcium systems: Influence of $\mathrm{pH}$, ionic strength, and temperature on the gelation of pectins with different degrees of methylation. Carbohydrate Research, 240, 219-232.

Grant, G. T., Morris, E. R., Rees, D. A., Smith, P. J. C., \& Thom, D. (1973). Biological interactions between polysaccharides and divalent cations: The egg-box model. FEBS Letters, 32, 195-198.

Harris, P. J., Blakeney, A. B., Henry, R. J., \& Stone, B. A. (1988). Gas chromatographic determination of the monosaccharide composition of plant cell wall preparations. Journal of the Association Official Analytical Chemistry, 71, 272-275.

Huisman, M. M. H., Schols, H. A., \& Voragen, A. G. J. (1996). Changes in cell wall polysaccharides from ripening olive fruits. Carbohydrate Polymers, 31, 123-133.

Kalapathy, U., \& Proctor, A. (2001). Effect of acid extraction and alcohol precipitation conditions on the yield and purity of soy hull pectin. Food Chemistry, 73, 393-396

Khalid, F., Renard, C. M. G. C., R'zina, Q., \& Thibault, J.-F. (2001). Extraction and composition of pectins and hemicelluloses of cell walls of sugar beet roots grown in Morocco. International Journal of Food Science and Technology, 36, 35-46.

Lopes da Silva, J. A., \& Gonçalves, M. P. (1994). Rheological study into the ageing process of high methoxyl pectin/sucrose aqueous gels. Carbohydrate Polymers, 24, 235-245.

Lopes da Silva, J. A., Gonçalves, M. P., Doublier, J. L., \& Axelos, M. A. (1996). Effect of galactomannans on the viscoelastic behaviour of pectin/calcium networks. Polymer Gels and Networks, 4, 65-83.

Mafra, I., Lanza, B., Reis, A., Marsilio, V., Campestre, C., De Angelis, M., \& Coimbra, M. A. (2001). Effect of ripening on texture, microstructure and cell wall polysaccharide composition of olive fruit (Olea europaea). Physiologia Plantarum, 111, 439-447.

May, C. D. (1990). Industrial pectins: Sources, production and applications. Carbohydrate Polymers, 12, 79-99.

Micard, V., \& Thibault, J.-F. (1999). Oxidative gelation of sugar-beet pectins: Use of laccases and hydration properties of the cross-linked pectins. Carbohydrate Polymers, 39, 265-273.

Morris, E. R., Powel, D. A., Gidley, M. J., \& Rees, D. A. (1982). Conformations and interactions of pectins. I. Polymorphism between gel and solid states of calcium polygalacturonate. Journal of Molecular Biology, 155, 507-516.

Powel, D. A., Morris, E. R., Gidley, M. J., \& Rees, D. A. (1982). Conformations and interactions of pectins. II. Influence of residue sequence on chain association in calcium pectate gels. Journal of Molecular Biology, 155, 517-531.

Price, M. L., \& Butler, L. G. (1977). Rapid visual estimation and spectrophotometric determination of tannin content of sorghum grain. Journal of Agriculture and Food Chemistry, 25, 1268-1273.

Renard, C. M. G. C., Champenois, Y., \& Thibault, J.-F. (1993). Characterisation of the extractable pectins and hemicelluloses of the cell wall of glasswort (Salicornia ramosissima). Carbohydrate Polymers, 22, 239-245.

Ridley, B. L., O’Neill, M. A., \& Mohnen, D. (2001). Pectins: Structure, biosynthesis, and oligogalacturonide-related signaling. Phytochemistry, 57, 929-967.

Saviozzi, A., Riffaldi, R., Levi-Minzi, R., Scagnozzi, A., \& Vanni, G. (1993). Decomposition of vegetation-water sludge in soil. Bioresource Technology, 44, 223-228.

Selvendran, R. R., March, J. F., \& Ring, S. G. (1979). Determination of aldoses and uronic acid content of vegetable fibre. Analytical Biochemistry, 96, 282-292.

Vierhuis, E (2002). Structural characteristics of polysaccharides from olive fruit cell walls in relation to ripening and processing. $\mathrm{PhD}$ Thesis, Wageningen University.

Voragen, A. G. J., Pilnik, W., Thibault, J.-F., Axelos, M. A. V., \& Renard, C. M. G. C. (1995). Pectins. In A. M. Stephen (Ed.), Food polysaccharides and their applications (pp. 287-339). New York: Marcel Dekker.

Waldron, K. W., \& Selvendran, R. R. (1990). Composition of the cell walls of different asparagus (Asparagus officinalis) tissues. Physiologia Plantarum, 80, 568-575.

Willats, W. G. T., McCartney, L., Mackie, W., \& Knox, J. P. (2001). Pectin: Cell biology and prospects for functional analysis. Plant Molecular Biology, 47, 9-27.

Willis, R. B., Montgomery, M. E., \& Allen, P. R. (1996). Improved method for manual, colorimetric determination of total Kjeldahl nitrogen using salicylate. Journal of Agriculture and Food Chemistry, 44, 1804-1807. 